\title{
Personal Stare Decisis, HIV Non-Disclosure, AND THE DECISION IN MABIOR
}

\author{
ELAINE CRAIG*
}

\begin{abstract}
The doctrine of stare decisis has long been considered foundational to our judicial system. The concept operates in two manners: (1) to bind lower courts to the previous decisions of higher courts, which is known as vertical precedent; and (2) horizontal precedent - the practice of a court adhering to its own prior decisions.
\end{abstract}

This article examines the adherence to horizontal precedent by appellate courts and, in particular, how appellate judges that have substantially disagreed with the majority through a concurring judgment should treat this concurrence in a subsequent case in which the majority's legal rule has become a horizontal precedent. The discussion focuses primarily on Chief Justice McLachlin's adherence to the majority's decision in R. v. Cuerrier in her unanimous decision in R. v. Mabior, even though she wrote a concurring opinion in Cuerrier strongly disagreeing with the majority's decision. This article argues that if precedent must prevail, Chief Justice McLachlin should have followed her own personal stare decisis rather than horizontal precedent.

\section{TABLE OF CONTENTS}

I. INTRODUCTION . . . . . . . . . . . . . . . . . . . . . 207

II. THE RELATIONSHIP BETWEEN THE DOCTRINE OF HORIZONTAL Precedent and the Concept of Personal Stare Decisis . . . . . . 208

III. PERSONAL STARE DECISIS:

CUERRIER AND MABIOR AS A CASE STUdy . . . . . . . . . . . . 215

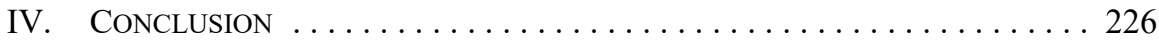

\section{INTRODUCTION}

The doctrine of precedent or stare decisis - letting decided matters stand — is considered foundational to our judicial system. ${ }^{1}$ The concept operates to bind lower courts to the previous decisions of higher courts. This is the notion of hierarchical or vertical precedent. ${ }^{2}$ There is also a concept of horizontal precedent recognized by our courts - the practice of a court adhering to its own prior decisions. While not bound by its own prior decisions, the principle of horizontal precedent discourages a court from overruling a prior decision of the same court. ${ }^{3}$

Assistant Professor, Schulich School of Law at Dalhousie University. Thank-you to Isabel Grant and Steve Coughlan for their insight, guidance, and contributions. Thank-you to Ashley Greene and Joanna Schoeppe for their research assistance. I gratefully acknowledge the funding support of the Social Sciences and Human Research Council through the Insight Grant program.

$R v$ Neves, 2005 MBCA 112, [2006] 4 WWR 464, Steel, Freedman JJA [Neves] ("[t]he principle of stare decisis is a bedrock of our judicial system" at para 90).

$2 \quad$ See Evan H Caminker, "Why Must Inferior Courts Obey Superior Court Precedents?" (1994) 46:4 Stan L Rev 817.

Jeffrey C Dobbins, "Structure and Precedent" (2010) 108:8 Mich L Rev 1453 at 1461-62. 
The focus of this article is on adherence to horizontal precedent by appellate courts. More specifically, it examines how appellate judges that have substantively disagreed with the majority through a concurring judgment should treat this concurrence in a subsequent case in which the majority's legal rule has become a horizontal precedent.

The remainder of the article is divided into two parts. Part II reviews the principle of stare decisis, the values it is purported to protect and promote, and the Supreme Court of Canada's recent treatment of the doctrine. It also discusses the concept of personal stare decisis (maintaining consistency with one's own prior jurisprudence) and advances a framework for addressing the relationship between horizontal precedent and individuated judgment by appellate courts.

Part III offers a case study of the Supreme Court of Canada's decisions in R. v. Cuerrier ${ }^{4}$ and R. v. Mabior ${ }^{5}$ in an effort to demonstrate a circumstance in which overturning Cuerrier (a horizontal precedent) in favour of adhering to personal stare decisis would better serve the rule of law and institutional legitimacy of the Court. Although Chief Justice McLachlin wrote the unanimous decision in Mabior affirming (and expanding the reach of) the Cuerrier approach, 15 years earlier she wrote a concurring opinion disagreeing strongly with the majority's reasoning in Cuerrier. In her Cuerrier concurrence, Justice McLachlin (as she then was) predicted exactly the types of problems with the majority approach that have come to bear. Part III advances the claim that, if precedent must prevail, Chief Justice McLachlin ought to have based her decision in Mabior on a concept of personal stare decisis rather than horizontal precedent. ${ }^{6}$ In other words, if she was determined to follow prior judicial reasoning she should have returned to the rationale articulated in her concurring opinion in Cuerrier rather than affirming the approach adopted by the majority — an approach with which she took significant issue at the time it was adopted. The principle of stare decisis is an inherently conservative concept and one without any intrinsic value. Its worth is functional and when application of the principle undermines the functions or values justifying it, the doctrine of letting decided matters stand should be ignored.

\section{The Relationship Between the Doctrine of Horizontal Precedent ANd The Concept of Personal Stare Decisis}

Judicial adherence to prior precedent from the same court is said to serve two important and related functions: (1) it protects the rule of law; and (2) it preserves the legitimacy of the court as an institution. ${ }^{7}$ Horizontal stare decisis is thought to protect the rule of law by ensuring that laws are consistent, coherent, predictable, and thus accessible. ${ }^{8}$ Horizontal stare decisis supports the institutional legitimacy of the court by protecting against a system in

[1998] 2 SCR 371 [Cuerrier].

2012 SCC 47, [2012] 2 SCR 584 [Mabior].

The term "personal stare decisis" is borrowed from a law review article of the same name. See Reed C Lawlor, "Personal Stare Decisis" (1968) 41:1 S Cal L Rev 73.

A third justification for the doctrine of precedent is that it serves justice by ensuring that like cases are treated alike. This equality based value is not treated separately in this article on the assumption that, to a certain degree, it is already included in the rule of law principle that the law applies to everyone. Certainty in the law, and the predictability it breeds, is often cited as the justification for the doctrine of precedent. See David Lyons, "Formal Justice and Judicial Precedent" (1985) 38:3 Vand L Rev 495 at 496. One fundamental aspect of the rule of law is an order of knowable laws. This requires certainty. See Reference Re Manitoba Language Rights, [1985] 1 SCR 721 [Manitoba Language Rights]. 
which the law changes, or is perceived to change, with each new judicial appointment. ${ }^{9}$ The common law is thought to be greater than the sum of its individual judicial parts. The institutional legitimacy of appellate courts would be threatened by a public perception that the common law is developed by the unpredictable whims of any one particular judge.

While the law must be coherent, consistent, and predictable, there is also an expectation that judge-made laws that are thought to be wrong will be corrected. ${ }^{10}$ As Lord Denning noted, "[t]he doctrine of precedent does not compel your Lordships to follow the wrong path until you fall over the edge of the cliff." "In his discussion of the rule of law, Jeremy Waldron draws on the observation of Plato's visitor in The Statesman: "[the law] is like a stubborn, stupid person who refuses to allow the slightest deviation from or questioning of his own rules, even if the situation has in fact changed." 12 To maintain faith in the legitimacy of the court - to avoid a public perception of the court that echoes that of Plato's visitor judicial reliance on stare decisis must be reasoned and thoughtful. ${ }^{13}$ In rejecting the suggestion that vertical stare decisis is a constitutional principle requiring lower courts to rigidly apply the decisions of higher courts, the Court in Carter v. Canada (AG) commented: "stare decisis is not a straitjacket that condemns the law to stasis." equally, if not more, true for an appellate court considering its own prior decisions.

Similarly, laws (as expounded by judges) that produce unintelligible standards or inconsistent outcomes - in other words, laws that undermine central attributes of the rule of law - ought not to be upheld in the name of stare decisis. To do otherwise would incorporate illogic at the very core of the doctrine of precedent. If it is to be relied upon, the principle of stare decisis should be employed in service of accessibility and predictability. ${ }^{15}$

Oona A Hathaway, "Path Dependence in the Law: The Course and Pattern of Legal Change in a Common Law System" (2001) 86:2 Iowa L Rev 601 ("stare decisis helps to reassure the public that the courts' decisions are not capricious, but are based instead on consistent and legitimate decision making" at 652).

$10 \quad$ Neves, supra note 1 at para 90.

Ostime (Inspector of Taxes) v Australian Mutual Provident Society (1959), [1960] AC 459 (HL).

Jeremy Waldron, "Thoughtfulness and the Rule of Law" (2011) New York University School of Law Public Law and Legal Theory, Working Papers 263 at 1, citing Plato, Statesman, Julia Annas \& Robin Waterfield, eds, translated by Robin Waterfield (Cambridge: Cambridge University Press, 1995) at 59. In Canada v Craig, 2012 SCC 43, [2012] 2 SCR 489 [Craig], Justice Rothstein identified significant criticism of a precedent by academics, courts and others as one of the reasons to overturn the Court's earlier decision in Moldowan v The Queen (1977), [1978] 1 SCR 480 [Moldowan]: "there has been significant judicial, academic and other criticism of Moldowan from its issuance in 1977. In light of this criticism, it is appropriate for this Court to take notice and acknowledge the difficulties identified with the Moldowan interpretation of s. 31(1)" at para 29. See also Planned Parenthood of Southeastern Pennsylvania v Casey, 505 US 833 at 854 (1992) 1993) [Casey] for a discussion of this issue by United States Supreme Court Justices O'Connor, Kennedy, and Souter.

142015 SCC 5, [2015] 1 SCR 337 at para 44 [Carter] (affirming the Court's conclusion in Canada (AG) $v$ Bedford, 2013 SCC 72, [2013] 3 SCR 1101, McLachlin CJC [Bedford] that trial courts may reconsider settled rulings of higher courts: "(1) where a new legal issue is raised; and (2) where there is a change in the circumstances or evidence that "fundamentally shifts the parameters of the debate"' at para 42). SCR $740[B(K G)] ; R v$ Robinson, [1996] 1 SCR 683. 
In this way, the same values - clarity, consistency, certainty, and coherence - that mandate devotion to the principle of stare decisis in some cases demand that prior judgments be overturned in other cases. ${ }^{16}$ The legitimacy of the court and the rule of law are at stake both in an appellate court's decisions to uphold a previous precedent and in the decision to overturn one. Allowing prior precedent to bind present decisions where changed circumstances call for different policy choices is an example of the tail wagging the dog. ${ }^{17}$ New knowledge, evidence of significant shifts in social consensus, and the evolution of legal principles require courts at all levels to reconsider decided matters. ${ }^{18}$

The Supreme Court of Canada's approach to horizontal precedent recognizes these basic concepts. ${ }^{19}$ As Debra Parkes observes in her treatment of the doctrine of stare decisis, "the notion that Canadian appellate judges slavishly adhere to outdated precedent in a manner contrary to 'common justice and the general reason of mankind' does not accurately describe the current reality." ${ }^{20}$ In fact, in recent years, there is an increased inclination by the Supreme Court of Canada to overrule its own decisions. " "[T] his Court has signalled its willingness to adapt and develop common law rules to reflect changing circumstances in society at large.... [T] he courts can and should make incremental changes to the common law to bring legal rules into step with a changing society." 22

While the extent to which appellate courts should be bound by their prior decisions remains a matter of debate, the Supreme Court of Canada has stated explicitly that, provided there are substantial reasons for doing so, the Court should overrule prior precedent if it concludes that the issue was wrongly decided. ${ }^{23}$ In one of its most recent discussions of horizontal stare decisis the Court recognized a number of reasons for overruling a prior precedent. ${ }^{24}$ The reasons identified by the Court in Fraser can be summarized as follows: the

Justice Kennedy of the Supreme Court of the United States described this phenomenon as follows: "The obligation to follow precedent begins with necessity, and a contrary necessity marks its outer limit.... [W] hen this Court reexamines a prior holding, its judgment is customarily informed by a series of prudential and pragmatic considerations designed to test the consistency of overruling a prior decision with the ideal of the rule of law, and to gauge the respective costs of reaffirming and overruling a prior case." Casey, supra note 13 at 854.

17 Neither vertical nor horizontal precedent should be binding when social changes or new knowledge call for a different decision. See Bedford, supra note 14 ("[s]imilarly, the matter may be revisited if new legal issues are raised as a consequence of significant developments in the law, or if there is a change in the circumstances or evidence that fundamentally shifts the parameters of the debate" at para 42). See also Carter, supra note 14 (addressing vertical precedent and concluding that the trial judge was entitled to revisit Rodriguez v British Columbia (AG), [1993] 3 SCR 519). Carter, ibid at para 47.

Craig, supra note 13, Rothstein JA ("in making this decision [to overrule one of its own previous decisions] the Supreme Court engages in a balancing exercise between the two important values of correctness and certainty. The Court must ask whether it is preferable to adhere to an incorrect precedent to maintain certainty, or to correct the error" at para 27); Bedford, supra note 14; Carter, ibid. Debra Parkes, "Precedent Unbound? Contemporary Approaches to Precedent in Canada" (2006) 32:1 Man LJ 135 at 135 [citations omitted].

$21 \quad$ Parkes, ibid. See Ontario (AG) v Fraser, 2011 SCC 20, [2011] 2 SCR 3 [Fraser]; R v Henry, 2005 SCC 76, [2005] 3 SCR 609; Chaulk, supra note 15; B (KG), supra note 15; United States v Burns, 2001 SCC 7, [2001] 1 SCR 283 [Burns]; $R$ v Salituro, [1991] 3 SCR 654 [Salituro]. This is a marked shift from decades earlier during which time the Court was inclined to only overrule itself where the previous case had inadvertently mistaken the law. See e.g. Binus $v$ The Queen, [1967] SCR 594 at 601, discussed in Ian Bushnell, "Justice Ivan Rand and the Role of a Judge in the Nation's Highest Court" (2010) 61 UNBLJ 101 at 127.

22 Salituro, ibid at 666.

23 Craig, supra note 13; Fraser, supra note 21 at para 130.

Fraser, ibid at paras $129-37$. 
prior decision fails to reflect Charter $^{25}$ values; it creates uncertainty contrary to the values of clarity and certainty that underpin stare decisis; the prior decision disadvantages the accused by expanding the scope of criminal law beyond its normal limits; the prior decision is unworkable in its application; principles of law have developed that undermine the validity of the precedent; facts have so changed, or come to be viewed so differently, as to have deprived the old rule of its justification; the value of correcting the error outweighs the values of adhering to stare decisis; and the legislature is not likely to correct the problem in an expeditious fashion. The Supreme Court has also explicitly rejected its own previous decisions on the basis that they "do not withstand principled scrutiny." ${ }^{26}$ In other words, the Court has refused to follow horizontal precedent on the basis that the prior reasoning was simply wrong.

One factor that is sometimes in tension with the principle of stare decisis is the role of the individual appellate judge. ${ }^{27}$ The dominant construct of the judicial role is as guardian or trustee of the common law. According to this account, "judges act as trustees of the corpus of the common law, maintaining its integrity through fidelity to past decisions and continuing consideration of fit and consistency between and among various areas of the law as they develop." 28 This articulation of judicial decision-making emphasizes its institutional rather than individual nature. ${ }^{29}$ In its early years there was a tendency by the Supreme Court of Canada to produce seriatim opinions in which each member of the Court wrote his own decision. Over time a shift towards less individualized authorship, and greater unanimity has occurred..$^{30}$ Presumably, unanimous decisions from Canada's highest Court are thought to have a dignity, authority, and institutional weight that might not be attributed to judge by judge seriatim decisions.

The emphasis on the institutional nature of the adjudicative role would suggest that consideration of internal consistency within an individual judge's jurisprudence is not relevant: without a change in circumstance to warrant overturning it, appellate judges are bound by prior horizontal precedent regardless of their personal legal opinions. However, the numerous academic treatments of an individual appellate judge's canon of case law suggest that it is in fact quite common to examine legal reasoning in a manner cognizant of the individual jurist. ${ }^{31}$ The Supreme Court itself implicitly recognizes that individual authorship by appellate judges does feature in our understanding of a particular law. It does this by the the Canada Act 1982 (UK), 1982, c 11 [Charter].

Health Services and Support - Facilities Subsector Bargaining Assn v British Columbia, 2007 SCC 27, [2007] 2 SCR 391 at paras 22-36 (rejecting the conclusion in two prior decisions - and the reasoning supporting that conclusion - that collective bargaining is not protected under section 2(d) of the Charter.

27 See e.g. Craig S Lerner \& Nelson Lund, "Judicial Duty and the Supreme Court's Cult of Celebrity" (2010) 78:6 Geo Wash L Rev 1255 at 1276 (arguing that the practice of authoring individually identified dissenting and concurring reasons can create tensions with the rule of law as typically understood).

28 Sarah MR Cravens, "In Good Conscience: Expressions of Judicial Conscience in Federal Appellate Opinions" (2013) 51:1 Duq L Rev 95 at 102.

Over time the Supreme Court of Canada's approach has changed. See Peter McCormick, “"With Respect ...'-Levels of Disagreement on the Lamer Court 1990-2000” (2003) 48:1 McGill LJ 89.

McCormick, ibid at 96.

See e.g. Philip Girard, Bora Laskin: Bringing Law to Life (Toronto: University of Toronto Press for The Osgoode Society for Canadian Legal History, 2005) (biography of Bora Laskin); Ellen Anderson, Judging Bertha Wilson: Law as Large as Life (Toronto: University of Toronto Press for The Osgoode Society for Canadian Legal History, 2001) (biography of Bertha Wilson). 
way in which its decisions are reported. For example, were it irrelevant, the Supreme Court of Canada would have no reason to denote authorship of those decisions that garner unanimity among the judges. However, often authorship of the reasons for a unanimous decision is attributed to a particular judge or judges. ${ }^{32}$ Yet in other cases the Court preserves anonymity by issuing judgments from "THE COURT" as a whole. ${ }^{33}$ Controversial unanimous judgments have been issued in both formats. ${ }^{34}$ It seems plausible to assume that these choices by the Court are neither neutral nor random, but rather indicative of the fact that authorship is in some way, in some cases, significant to the Court itself.

The area where the individuated aspect of appellate jurisprudence is thrown most sharply into relief involves the issuance of dissenting decisions and judgments that concur with the majority's outcome but offer legal reasoning that differs from that of the majority. A concurrence in outcome should be distinguished from those opinions (simple concurrences) in which a judge concurs with the outcome and the majority's reasons but decides to write her own judgment. The former - a concurrence in outcome only — is in fact a dissent from the reasoning of the majority's opinion. ${ }^{35}$ Concurrences of this type are not uncommon at the Supreme Court of Canada. ${ }^{36}$

Judicial decisions do not express a preference; they express a judgment. When judges disagree about the legal reasoning that supports a decision, they are each asserting that the other is wrong - this is what distinguishes a preference from a judgment. ${ }^{37}$ As Peter McCormick has argued, a jurist's decision to issue a separate and concurring opinion, despite agreeing with the outcome, often indicates a particularly deep fissure in the Court. ${ }^{38}$ Issuing concurring opinions requires expending precious and finite judicial time as well as the cost in political capital of revealing a divided court. In many cases, a judge who is willing to expend these resources to write a separate opinion even though they agree with the outcome of the case is a judge who has serious reservations about the legal reasoning of the majority. ${ }^{39}$ Moreover, while a judge may dissent from the majority as a matter of principle or because

See e.g. Bedford, supra note 14; Saskatchewan (Human Rights Commission) v Whatcott, 2013 SCC 11, [2013] 1 SCR 467, Rothstein JA [Whatcott].

33 See e.g. $R$ v Olson, [1989] 1 SCR 296; Reza v Canada, [1994] 2 SCR 394.

34 See e.g. Canada (Prime Minister) v Khadr, 2010 SCC 3, [2010] 1 SCR 44; Burns, supra note 21; Reference re Secession of Quebec, [1998] 2 SCR 217; Manitoba Language Rights, supra note 8, in which reasons for judgment were delivered by THE COURT. See Bedford, supra note 14 and Whatcott, supra note 32, for unanimous decisions in controversial cases where authorship of the reasons was identified.

35 Igor Kirman, "Standing Apart to Be a Part: The Precedential Value of Supreme Court Concurring Opinions" (1995) 95:8 Colum L Rev 2083. Judges in some concurrences actually describe their opinion as a dissent from the reasoning of the majority. See e.g. Justice McLachlin's (as she then was) concurring decision in $R v$ Potvin, [1993] 2 SCR 880 ("I have read the reasons of my colleague, Justice Sopinka, and must respectfully dissent from his views on how appellate delay is treated" at 886).

36 See Peter McCormick, "The Choral Court: Separate Concurrence and the McLachlin Court, 2000-2004" (2005-2006) 37:1 Ottawa L Rev 1 [McCormick, "The Choral Court"] ("[i]n this new century, the delivery of separate concurring reasons by the Supreme Court of Canada seems to have reached a new equilibrium, less frequent than was the case for the previous decade and a half, but frequent and regular enough to suggest a persisting feature of the way the Court explains itself to its broader public" at 3). Lewis A Kornhauser \& Lawrence G Sager, "Unpacking the Court" (1986) 96:1 Yale LJ 82 at 85:

The limited and sovereign attributes of a preference combine to make it perfectly possible for two individuals to disagree strongly in their preferences without either of them being wrong.... In contrast ... a judgment advances a "truth," that is, a proposition to which all other right-thinking persons who may confront the issue must adhere. The claim is decidedly not sovereign in the sense that an individual's adherence to the judgment does not itself justify it. Two persons may disagree in their judgments, but when they do, each acknowledges that (at least) one of them is wrong. McCormick, "The Choral Court," supra note 36. Ibid. 
of a different interpretation or application of the facts, judgments that concur in the result but offer different legal reasons always involve some degree of disagreement over legal principle. ${ }^{40}$ Concurring judgments involve a claim that some aspect of the majority's legal reasoning is wrong: "[a]n opinion that gets the reasons wrong gets everything wrong which it is the function of an opinion to produce." 41 A concurring opinion represents an official, public pronouncement articulating disagreement with the majority. ${ }^{42}$ Moreover, " $[\mathrm{t}]$ he typical concurrence is not motivated by a small matter." ${ }^{, 3}$ For the most part, judges write concurring opinions because of significant, substantive disagreement with the majority opinion. ${ }^{4}$ McCormick argues that, in light of the costs incurred in doing so, the willingness to write concurring decisions reveals a commitment on the part of Supreme Court judges to "getting it right." ${ }^{45}$ It also suggests some relationship between judicial authorship and individuated appellate judging.

Assuming this is true, how should the doctrine of stare decisis inform circumstances in which an appellate judge has, in a previous decision, expressed disagreement with a legal rule that has become horizontal precedent in a present case? While a literature on concurrences has developed, ${ }^{46}$ the issue of how an appellate judge should treat their own such opinions has not been closely examined.

This article argues that the relationship between individuated appellate jurisprudence (in particular in the form of concurrent judgments) and the principle of stare decisis should be conceptualized in light of the values underpinning the principle of stare decisis. Again, these values include the rule of law and the institutional legitimacy of the Court. This would mean that the same kinds of factors that determine whether a horizontal precedent should be followed - consistency, predictability, coherence, and accessibility — should inform the application of what might be called personal stare decisis in a circumstance where an appellate court judge has previously written a concurrence that substantively disagrees with

40 Nancy Maveety, "Concurrence and the Study of Judicial Behavior in American Political Science" (2003) 8 Juridica Intl 173 (dissents are generally considered an important and understandable part of the common law process, whereas concurrence "still retains something of a taint to it - that it is somehow more destructive of judicial or judicial institutional integrity, more invidious with respect to legal clarity, less cooperative and more persnickety than dissent" at 174).

41 Antonin Scalia, “The Dissenting Opinion” (1994) 19:1 J Supreme Court Hist 33 at 33. Justice Marshall Rothstein, "The Role of Dissenting and Concurring Reasons in the Supreme Court of Canada's Charter Jurisprudence" (2009) 27 NJCL 1 ("I admit that sometimes dissents or concurring reasons can be sharply worded and perhaps they can be unduly critical. They may not need to be, but when you think that someone else is wrong you feel that you have to be clear about it" at 5).

42 Peter McCormick, "Standing Apart: Separate Concurrence and the Modern Supreme Court of Canada, 1984-2006" (2008) 53:1 McGill LJ 137 at 147 [McCormick, "Standing Apart"]:

what is important is not just that a judge is claiming one of his colleagues made a mistake about the law (which could be done in a personal note, or over coffee), but that the judge is stating this publicly in an official pronouncement of the Court. Part of the motive in writing separately may be intellectual ("This is wrong, and I want the record to show that I know it is wrong"), but part of it may also be tactical, with the opinion serving as a signal to those concerned elements in civil society ("I agree with you, I'm doing what I can, give me more to work with").

43 Ibid at 149 (the author conducted a lengthy examination of concurring opinions in the Supreme Court of Canada between 1984 and 2006).

44 Ibid.

45 McCormick, "The Choral Court," supra note 36 ("the fact that judges are so concerned with 'getting it right' that they seek to distance themselves from colleagues who got the outcome right ... is a strong vindication ... that we should take the judges at their word by regarding substantive legal analysis as the core of what they do" at 31).

46 See e.g. Kirman, supra note 35; McCormick, "Standing Apart," supra note 42; Laura Krugman Ray, "The Justices Write Separately: Uses of the Concurrence by the Rehnquist Court" (1990) 23:4 UC Davis L Rev 777. 
what has become a horizontal precedent in a case that is now before her. In deciding whether to adhere to the horizontal precedent, maintain consistency with one's past decision (personal stare decisis), or reject both, appellate judges should consider whether the prior majority precedent has created certainty and clarity, whether the prior decision has been workable in its application, whether the prior precedent has expanded the scope of the criminal law to the disadvantage of the accused, and whether the interpretation and application of the majority's decision by lower courts reflects Charter values. In addition, she should consider whether knowledge has changed such that her concurrent reasons are no longer justified, whether principles of law have since developed that undermine the validity of her concurrent reasoning, and whether social circumstances have shifted in a manner that demands different policy choices. In other words, in making her decision, she should be guided by an assessment of whether the rule of law values underpinning stare decisis are better served by upholding the horizontal precedent, adhering to personal stare decisis, or rejecting both.

Moreover, in terms of judicial authorship, in the interests of preserving institutional legitimacy, when writing decisions appellate judges faced with a horizontal precedent with which they previously expressed substantive disagreement should be explicit about their treatment of the prior concurrence. This is true whether they conclude that the values underpinning stare decisis are better served by adhering to the precedent or by exercising personal stare decisis. A judge who has publicly and officially denounced a particular legal rule that they subsequently make a decision to uphold, should explain their reversal. They should explain why their previous reasoning is no longer justified. A failure to do so risks creating Plato's visitor's perception that stare decisis is applied blindly and irrationally. Similarly, a judge that authors a decision which favours their own prior legal reasoning, rather than following a horizontal precedent, risks threatening the legitimacy of the Court as an institution unless they articulate the reasons why following the horizontal precedent would compromise the values underpinning the principle of stare decisis. Unless they show, for example, that the horizontal precedent has created uncertainty or inconsistency in the law, that social circumstances have changed, or that the horizontal precedent has greatly expanded the reach of the criminal law to the disadvantage of the accused, a decision to ignore precedent in favour of one's prior concurrence risks disrupting the perception of the Court as an institution - as an adjudicative body greater than the sum of its individual adjudicator parts.

In an effort to demonstrate how this approach to the relationship between horizontal precedent and individuated appellate jurisprudence should function, the remainder of this article applies these claims to the Supreme Court of Canada's legal approach to the nondisclosure of HIV to one's sexual partner. The Supreme Court of Canada's most recent approach to HIV non-disclosure exemplifies a circumstance in which personal stare decisis would have been justified - that is to say, a circumstance in which following a prior precedent risks perpetuating the types of legal uncertainties that undermine the rule of law. The Court's recent decision in Mabior also demonstrates why it is desirable for appellate judges to be explicit about their treatment of their own prior legal reasoning. 


\section{Personal Stare Decisis: Cuerrier and Mabior as a Case Study}

The foundation for the current legal landscape in Canada with respect to the criminalization of HIV non-disclosure is in large measure a product of a 1998 decision of four former justices of the Supreme Court of Canada in Cuerrier. ${ }^{47}$ In Cuerrier, the majority of the Court concluded that there is a duty to disclose to sexual partners any "significant risk of serious bodily harm." ${ }^{48}$ Failure to disclose such risk will vitiate consent to sexual intercourse. In Cuerrier, the majority concluded that the risk of contracting HIV as a result of sexual intercourse can meet that test in circumstances where the complainant would not have consented had they known of the accused's HIV status. ${ }^{49}$ As a result, the current criminal law response to non-disclosure of HIV positive status to one's sexual partners in Canada is based on the offences of assault, sexual assault, and aggravated sexual assault.

There are significant problems stemming from the legal approach to non-disclosure of HIV positive status adopted in Cuerrier. Two of the more prominent include overcriminalization and lack of certainty in the law. ${ }^{50} \mathrm{~A}$ third involves its potential to result in inequality and stereotypical reasoning by lower courts. ${ }^{51}$

The Supreme Court of Canada had an opportunity to reconsider the Cuerrier approach in 2012. ${ }^{52}$ In Mabior, the Court affirmed the test adopted by the majority in Cuerrier in a unanimous decision authored by Chief Justice McLachlin. ${ }^{53}$ Unfortunately, rather than address the overbreadth caused by Cuerrier, the Court extended the law's reach. ${ }^{54}$ In addition, while the decision in Mabior has resolved some uncertainty with respect to unprotected sex (failure to disclose HIV positive status prior to vaginal intercourse without a condom vitiates consent under Mabior), it has perpetuated other uncertainties and introduced new ones. ${ }^{55}$

Despite the significant role that Cuerrier has had on this area of law, it was far from a unanimous decision. Of the panel of seven, three jurists strongly disagreed with the majority's reasoning. ${ }^{56}$ Justice McLachlin (as she then was) was among them.

Supra note 4. The majority developed a two-part test to determine whether consent was vitiated by fraud. (1) There must be proof of dishonesty and either deprivation or risk of deprivation. The deprivation may consist of actual harm or a significant risk of harm. (2) The trier of fact must be convinced beyond a reasonable doubt that the complainant would not have consented to sex had they known that the accused was HIV positive.

Ibid.

Ibid at para 128 .

See Alison Symington, "Criminalization Confusion and Concerns: The Decade Since The Cuerrier Decision" (2009) 14:1 HIV/AIDS Policy \& Law Rev [Symington, "Criminalization Confusion"]; Isabel Grant, "The Prosecution of Non-Disclosure of HIV in Canada: Time to Re-Think Cuerrier" (2011) 5:1 McGill JL \& Health 7 [Grant, "Time to Re-Think Cuerrier"]; Isabel Grant, "Rethinking Risk: The Relevance of Condoms and Viral Load in HIV Nondisclosure Prosecutions" (2009) 54:2 McGill LJ 389 [Grant, "Rethinking Risk"].

Symington, "Criminalization Confusion," ibid.

Mabior, supra note 5.

Ibid.

See Isabel Grant, "The Over-Criminalization of Persons with HIV" (2013) 63:3 UTLJ 475 [Grant, "Over-Criminalization"] ("[i]t is beyond dispute that Mabior expands the scope of criminal liability beyond Cuerrier" at 482 [emphasis in original]).

Grant, "Over-Criminalization," ibid; Martha Shaffer, "Sex, Lies, and HIV: Mabior and the Concept of Sexual Fraud” (2013) 63:3 UTLJ 466; Alison Symington, “Injustice Amplified By HIV Non-Disclosure Ruling" (2013) 63:3 UTLJ 485 [Symington, "Injustice Amplified"].

56 Cuerrier, supra note 4. Justice Cory wrote for the four-person majority. Justice L'Heureux-Dubé wrote a seperate concurrence. Justice McLachlin (joined by Justice Gonthier) wrote a separate concurrence. 
In her prescient concurrence in Cuerrier, Justice McLachlin raised a number of problems that she predicted would arise as a result of the majority's reasoning. ${ }^{57}$ Her two main concerns were that the approach the majority advocated was too broad and that it would create uncertainty in the law. ${ }^{58}$ She also expressed concern that the majority's approach would overly burden already marginalized communities. ${ }^{59}$

Justice McLachlin predicted that, if the "sweeping changes" proposed by the majority were accepted, "[1]iterally millions of acts, which have not to date been regarded as criminal, will now be criminalized. Individual liberty will be curtailed. Police, prosecutors, the courts and the prisons will be dramatically affected." ${ }^{60}$ In her view, such broad and sweeping changes to the criminal law should be made by Parliament. ${ }^{61}$ Parliament, she noted, can debate, commission studies, hold public hearings, and arrive at a considered conclusion as to whether such a broad expansion of the criminal law should be adopted. "Such changes fall outside the proper sphere of judicial law reform." ${ }^{63}$ She suggested that the "extension of the criminal law of assault proposed by Cory J. represents a curtailment of individual liberty sufficient to require endorsement by Parliament."

Justice McLachlin's apprehension about the potentially broad impact of the majority's reasoning was well founded. Today, Canada's criminal law approach to the issue of nondisclosure is more severe and broader-reaching than the approaches taken in other developed countries ${ }^{65}$ and the position taken by international organizations. ${ }^{66}$ Often the charge laid is aggravated sexual assault. ${ }^{67}$ This is because of the test adopted by the Court in Cuerrier. To vitiate consent on the basis of non-disclosure, the Crown must establish a significant risk of serious bodily harm. In establishing a significant risk of serious bodily harm, the Crown has simultaneously shown that the accused endangered the complainant's life - this converts sexual assault simpliciter into aggravated sexual assault. ${ }^{68}$ In other words, the elements for

Cuerrier, ibid. Justice McLachlin also disagreed with Justice L'Heureux-Dubé's approach. However, because Justice L'Heureux-Dubé's reasoning was not adopted by the Court, and as a result did not create the types of problems created by the Cuerrier majority, it will not be the focus of this discussion.

Ibid at paras $25-26$.

Ibid at para 55.

Ibid at para 54

Ibid at para 56.

Ibid.

Ibid at para 57.

Ibid at para 49.

See Grant, "Time to Re-Think Cuerrier," supra note 50 ("Canada has ... one of the highest levels of prosecution for the non-disclosure of HIV status to one's sexual partners of any developed country in the world" at 9). By 2011, when Grant conducted this research, there had been over 100 prosecutions in Canada. Grant notes that, not only are the rates of prosecution significantly higher in Canada than in countries such as Australia and the United Kingdom, but also the types of charges laid in Canada are more serious.

66 See Joint United Nations Programme on HIV/AIDS, Policy Brief: Criminalization of HIV Transmission, UNAIDS (August 2008), online: <www.unaids.org/en/media/unaids/contentassets/dataimport/pub/base document/2008/20080731 jc1513 policy_criminalization_en.pdf $>$ (UNAIDS, the joint United Nations Programme on HIV/AIDS, "urges governments to limit criminalization to cases of intentional transmission" at 1). See also World Health Organization, WHO technical consultation in collaboration with the European AIDS Treatment Group and AIDS Action Europe on the criminalization of HIV and other sexually transmitted infections (Copenhagen: WHO Regional Office for Europe, 16 October 2006) at 9-14, online: The Centre for HIV Law \& Policy <www.hivlawandpolicy.org/sites/www.hivlawand policy.org/files/WHO $\% 20$ consultation $\% 20$ on $\% 20 \mathrm{crim} \% 20$ laws.pdf $>$.

67 See Eric Mykhalovskiy \& Glenn Betteridge, "Who? What? Where? When? And with What Consequences? An Analysis of Criminal Cases of HIV Non-disclosure in Canada" (2012) 27:1 CJLS 31 at 50 .

68 Criminal Code, RSC 1985, c C-46, s 273(1). 
the offence recognized by the majority in Cuerrier correspond to the elements for the offence of aggravated sexual assault, not sexual assault simpliciter. This is why, subsequent to the decision in Cuerrier, it has become common for the Crown to lay charges of aggravated sexual assault. ${ }^{69}$

It is not only that Canada frequently prosecutes non-disclosure of HIV positive status with its most serious sexual offence (aggravated sexual assault) ${ }^{70}$ — in Canada, unlike in many other developed countries, the charges do not differ depending upon whether transmission occurs. ${ }^{71}$ Individuals have even been charged (and sometimes convicted) in non-disclosure cases where a condom was used and transmission did not occur. ${ }^{72}$

In addition to her concern that the "significant risk of serious bodily harm" test was overbroad, Justice McLachlin also predicted that it would create uncertainty. ${ }^{73}$ She argued that the rule arrived at by the majority in Cuerrier offered "no principled rationale for allowing some risks to vitiate consent to sex but excluding others." ${ }^{, 74}$ She concluded that the significant risk of serious bodily harm test introduced an unacceptable degree of uncertainty into the law. ${ }^{75}$ How would courts ascertain whether a risk was significant enough to qualify conduct as criminal? From whose perspective would significance be determined - the victim's, the accused's, or the police and prosecutors'? ${ }^{76}$ She rightly noted that " $[\mathrm{t}]$ he criminal law must be certain. If it is uncertain ... it becomes unfair. People who believe they are acting within the law may find themselves prosecuted, convicted, imprisoned and branded as criminals." 77 She argued that the serious consequences of a criminal conviction "should not turn on the interpretation of vague terms like 'significant' and 'serious.", 78

As with the issue of overbreadth, Justice McLachlin's concerns about the uncertainty that would be introduced into the criminal law by the majority's decision in Cuerrier were

Ibid at 5 .

Grant, "Time to Re-Think Cuerrier," supra note 50 ("the same charge of aggravated (sexual) assault is typically used regardless of the nature of the deception, whether the virus is transmitted, or whether there is an isolated incident of non-disclosure" at 42). See also Mykhalovskiy \& Betteridge, supra note 67 at 47 (as of 2012, transmission of the HIV virus did not occur in 39 percent of those cases that have resulted in conviction).

For cases in which charges were laid despite condom use see $R v$ Felix, 2013 ONCA 415, 298 CCC (3d) 121 [Felix], (concluding that where condom was used the accused must lead evidence of viral load); $R$ $v$ Mekonnen, 2009 ONCJ 643, [2009] OJ No 5766 (QL) [Mekonnen] (the Crown laid charges despite condom use; charges eventually stayed); $R v$ McGregor, 2008 ONCA 831, 94 OR (3d) 500 [McGregor] (sentencing decision in which the accused engaged in two acts of unprotected sex during an almost twoyear relationship in which a condom was used the remainder of the time; transmission did not occur. In increasing the sentence, the Court included a discussion of the year and a half of protected sex); $R v$ Murphy, [2013] OJ No 3903 (QL) (Sup Ct J) [Murphy], (conditional sentence imposed; accused had oral sex and vaginal sex with a condom that broke, no transmission occurred); $R \vee$ Kaotalok, 2013 NWTSC 36, [2013] NWTJ No $54(\mathrm{QL})$, (guilty plea after defence lawyer conceded realistic possibility of transmission despite use of condom). In R v Mabior (CL), $2008 \mathrm{MBQB}$ 201, 230 ManR (2d) 184, the accused was charged with ten counts of aggravated sexual assault. The trial judge concluded that only condom use in conjunction with undetectable viral load would sufficiently reduce the risk such that consent was valid. The Manitoba Court of Appeal overturned convictions in those cases where the accused "used condoms in a careful and consistent manner," $R v$ Mabior, 2010 MBCA 93, [2011] 2 WWR 211 at para 90 [Mabior CA].

Cuerrier, supra note 4 at para 48.

Ibid at para 47.

Ibid at para 48

Ibid.

Ibid.

Ibid. 
realized. In some post-Cuerrier cases, courts found that condom use would be sufficient to avoid conviction. ${ }^{79}$ In other cases, it was not. ${ }^{80}$ In some cases, a low or undetectable viral load was recognized as capable of lowering the risk to below significant. ${ }^{81}$ In other cases, viral load was not even mentioned.$^{82}$ In some cases, courts have suggested that it matters whether ejaculation occurred..$^{83}$ In others, courts have concluded that the absence of ejaculation is irrelevant. ${ }^{84}$ In some cases, the frequency with which the parties engaged in sex as relevant. ${ }^{85}$ In others, even one act of unprotected sex warranted conviction. ${ }^{86}$ In some cases, the court accepted that oral sex does not present a significant risk, ${ }^{87}$ while in others, the court found that unprotected oral sex does carry a risk of HIV transmission. ${ }^{88}$ The majority's significant risk of serious bodily harm test left people living with HIV with substantial uncertainty regarding their exposure to criminal liability. ${ }^{89}$

Justice McLachlin also highlighted the potential for issues of inequality posed by the majority's approach in Cuerrier. She noted that "because homosexuals, intravenous drug users, sex trade workers, prisoners, and people with disabilities are those most at risk of contracting HIV, the burden of criminal sanctions will impact most heavily on members of these already marginalized groups. ${ }^{.90}$ She expressed concern that such a broad extension of the criminal law would "have an adverse impact on the fight to reduce the spread of HIV and other serious sexually transmitted diseases." 91 She noted that the evidence before the Court suggested that a blanket duty to disclose could drive people living with HIV and AIDS underground, discouraging testing and treatment. ${ }^{92} \mathrm{~A}$ well-developed literature supports

$R v$ Nduwayo, 2006 BCSC 1972, [2006] BCJ No 3396 (QL) [Nduwayo]; $R v U(J), 2011$ ONCJ 457, $[2011]$ OJ No $4143(\mathrm{QL})[U(J)]$ (the Crown agreed that use of a condom was sufficient to avoid conviction).

$R v$ Wright, 2009 BCCA 514, 256 CCC (3d) 254 at para 40 [Wright] (trial judge was not required to instruct the jury to acquit if it had a reasonable doubt as to whether the accused wore a condom); McGregor, supra note 72 (sentencing decision involving repeated acts of protected sex and two acts of unprotected sex; court insinuates that even the protected sex was nonconsensual).

$R v$ Thomas, 2011 ONSC 7136, [2011] OJ No 6008 (QL) (court suggests a low viral load could be a relevant consideration - but was not in this case because the accused had engaged in numerous acts of unprotected sex before starting treatment to lower his viral load).

$R v$ Tippeneskum, 2011 ONCJ 219, [2011] OJ No 1925 (QL). It was also unclear whether the Crown could rely on evidence of average rates of transmission or whether specific evidence of the defendant's viral load was required: see Wright, supra note 80 (concluding that the court is entitled to rely on figures of the average rate of transmission).

$U(J)$, supra note 79 (acquitted in part on the basis that there was no ejaculation and no evidence of whether there was pre-ejaculate); Wright, ibid.

$R v S(F), 262$ CCC (3d) 472 (Ont CA).

$U(J)$, supra note 79; Nduwayo, supra note 79 (acquitted on the basis that a single incident of unprotected vaginal intercourse did not constitute a significant risk; accused was convicted on other counts involving repeated acts of unprotected sexual intercourse).

R C DC, 2008 QCCQ 629, [2008] JQ No 994 (QL), rev'd 2012 SCC 48, [2012] 2 SCR 626.

Murphy, supra note 72 (accused acquitted on charge of aggravated sexual assault for failing to disclose HIV status before allowing complainant to perform cunnilingus on her. This case was decided postMabior. However, Mabior does not address the issue of oral sex.)

$R v$ Mumford, [2009] OJ No 1637 (QL) (Sup Ct J); Rv Mumford, 2010 ONSC 5624, [2010] OJ No 4347 (QL) (sentencing decision).

For a discussion of this, see Grant, "Rethinking Risk," supra note 50; Sharon Cowan, "Offenses of Sex or Violence? Consent, Fraud, and HIV Transmission" (2014) 17:1 New Criminal L Rev 135; Shaffer, supra note 55.

Cuerrier, supra note 4 at para 55.

Ibid.

Ibid. 
Justice McLachlin's concerns about the inequalities perpetuated by the criminalization of HIV non-disclosure. ${ }^{93}$

To summarize, in her concurring judgment in Cuerrier, Justice McLachlin correctly predicted that the majority's approach would create significant problems: overbreadth, uncertainty, and inequality. Justice McLachlin attempted to provide a more incremental reform to the common law - one that would not "possess [the] unforeseeable and complex ramifications" 94 she accurately predicted would arise from the majority's significant risk of serious bodily harm test. She concluded that the common law should be restored to its former position in which consent to sexual contact would be vitiated where "the accused falsely represented to the complainant that he or she was disease-free when he knew or ought to have known that there was a high risk of infecting his partner." ${ }^{95}$ She emphasized that this would exclude from criminal liability sexual acts in which a condom was used: "Again, protected sex would not be caught; the common law pre-Clarence required that there be a high risk or probability of transmitting the disease." "J6 Justice McLachlin's approach rejected the significant risk of serious bodily harm test and, in its stead, suggested a modification to the definition of fraud vitiating consent to sexual touching that would criminalize the behaviour of individuals who engaged in unprotected sex after falsely representing to their sexual partner that they were disease free.

Justice McLachlin's reasoning in Cuerrier offered two potential standards by which to criminalize non-disclosure in a fashion more suitably tailored than that of the majority in Cuerrier. The first would rely on her determination that only "high risk" activity should be criminalized. ${ }^{97}$ Presumably, this approach would preclude convictions against individuals who failed to disclose their HIV positive status but who either used a condom or had a low viral load. ${ }^{98}$ This approach would respond, to some degree, to the issue of overbreadth but

See e.g. Alison Symington, "HIV Exposure as Assault: Progressive Development or Misplaced Focus?" in Elizabeth A Sheehy, ed, Sexual Assault in Canada: Law, Legal Practice and Women's Activism (Ottawa: University of Ottawa Press, 2012) 635 (discussing the stigmatizing effects of HIV criminalization and gender inequalities); Gregory M Herek, "Thinking About AIDS and Stigma: A Psychologist's Perspective" (2002) 30:4 JL Med \& Ethics 594 (discussing problematic social attitudes towards HIV/AIDS during the early years of the epidemic); Matthew Cornett, "Criminalization of the Intended Transmission or Knowing Non-Disclosure of HIV in Canada" (2011) 5:1 McGill JL \& Health 61; David Hoe, "Legal and Human Rights Challenges for People Living with HIV/AIDS: A Personal Perspective" (2002) 7:2/3 Can HIV/AIDS Pol'y \& L Rev 5 (for the suggestion that reducing stigma and prejudice will encourage HIV positive people to be more open about their status); D Rao et al, "Stigma and social barriers to medication adherence with urban youth living with HIV" (2007) 19:1 AIDS Care 28 (examining the impact of HIV stigma on one's willingness to access health care); Russell K Robinson, "Racing the Closet" (2009) 61:6 Stan L Rev 1463 (discussing social attitudes towards HIV positive African Americans); Aziza Ahmed et al, "Criminalizing consensual sexual behaviour in the context of HIV: Consequences, evidence and leadership" (2011) 6:S3 Global Public Health S357; Mykhalovskiy \& Betteridge, supra note 67.

Cuerrier, supra note 4 at para 65.

Ibid at para 70 .

Ibid at para 73 [citations omitted].

Ibid at para 70 . In 1998 when Cuerrier was decided, the issue of viral load was beyond the contemplation of the Court, and so Justice McLachlin was likely using "lack of condom" as a proxy for high risk. In other words, for her, there was only one standard articulated in her reasoning. With today's knowledge about the relationship between the transmission of HIV and viral load, a standard of high risk, and a standard based on unprotected sex cannot be conflated. This explains the suggestion that her concurrence in Cuerrier would give rise to two possible approaches.

98 See Mabior, supra note 5 at paras 98, 101 (condom use reduces the probability of HIV transmission by at least 80 percent; the risk of HIV transmission is reduced by 89 to 96 percent when the partner's viral load has been reduced through medical treatment). See also Symington, "Injustice Amplified," supra note 55 at 489 . 
would do little to alleviate the uncertainty produced by a legal test that still requires courts to ascertain whether a sexual interaction was high risk.

An alternative standard that could be drawn from Justice McLachlin's concurrent reasoning in Cuerrier would rely on the distinction she made between protected and unprotected sex. ${ }^{99}$ Complainants who have unprotected sex with the defendant without being made aware of the defendant's HIV positive status would be understood to not have consented to contact with diseased bodily fluids. ${ }^{100}$ This tactic would not respond as well as the first approach to the issue of overbreadth because it would continue to capture within the criminal law's reach individuals who engaged in unprotected sex but had a low or undetectable viral load. However, it would offer greater legal certainty. It would also preclude convictions against individuals who engaged in protected sex without disclosing their HIV positive status. Under either of these interpretations of Justice McLachlin's approach in Cuerrier, the temptation for the Crown to charge individuals with aggravated sexual assault would be eliminated. Without the significant risk of serious bodily harm test (which Justice McLachlin rejected) there would be no impetus for the Crown to lay an aggravated sexual assault charge rather than sexual assault simpliciter.

As noted, in 2012 the Supreme Court of Canada had the opportunity to revisit the criminal law approach to the non-disclosure of HIV adopted in Cuerrier. By the time Mabior was decided, Chief Justice McLachlin was the only remaining jurist from the Cuerrier Court still sitting on the Supreme Court of Canada. Writing on behalf of the unanimous court, Chief Justice McLachlin affirmed the majority's approach in Cuerrier, and addressed its failings by stipulating that a significant risk of serious bodily harm is established in circumstances where there is a "realistic possibility of transmission." ${ }^{101}$ Chief Justice McLachlin concluded that, with respect to vaginal intercourse, a realistic possibility of transmission exists unless a condom was used and the accused's viral load was low or undetectable. At best, the 2012 decision in Mabior maintains the problematic direction set by the majority in 1998. More likely, Mabior will expand the reach of the criminal law. While the majority in Cuerrier suggested (without deciding) that use of condoms could suffice to avoid conviction, ${ }^{102}$ and some lower courts had accepted this standard, ${ }^{103}$ under Mabior the accused must use a condom and have a low viral load to avoid conviction. ${ }^{104}$ Under Mabior, a realistic possibility of transmission means something less than a 1 in 10,0000 chance of infection. ${ }^{105}$ Trial judges in two Nova Scotia cases have expressed concern about the increased criminalization that will occur because of the Supreme Court of Canada's decision in Mabior. ${ }^{106}$ Mabior may

99

100

Cuerrier, supra note 4 at para 72.

Ibid.

Mabior, supra note 5 at para 91.

Cuerrier, supra note 4, Cory JA ("[t]o have intercourse with a person who is HIV-positive will always present risks. Absolutely safe sex may be impossible. Yet the careful use of condoms might be found to so reduce the risk of harm that it could no longer be considered significant so that there might not be either deprivation or risk of deprivation" at para 129).

See e.g. Nduwayo, supra note 79; Mabior CA, supra note 72.

Mabior, supra note 5 at para 94.

Symington, "Injustice Amplified," supra note 55 at 489; Grant, "Over-Criminalization," supra note 54 at 482: "But the Mabior 'realistic possibility of transmission' test is essentially a no-risk test, once the Court's requirement of condoms and low viral load is factored in."

$R v J T C, 2013$ NSPC 105, 336 NSR (2d) 249 at para 88; $R v J T C, 2013$ NSPC 88, 336 NSR (2d) 101 (Youth Ct) [JTC YC] ("[t]he effect of the Mabior and $C(D)$ decisions is the increased criminalization of persons living with HIV. The criminalizing of a non-disclosing HIV-positive person with an undetectable viral load who has unprotected sex is inconsistent with the Supreme Court's statement in 
also make the criminal law of non-disclosure more onerous in another respect. On one interpretation of Mabior — the one adopted by the Ontario Court of Appeal ${ }^{107}$ — the Court appears to have reversed the burden of proof on the issue of deprivation by placing an onus on the accused to disprove both the lack of a condom and a viral load of something other than low (or undetectable). ${ }^{108}$ Placing the burden on the accused to lead evidence of viral load may further disadvantage those already marginalized individuals whose limited access to medical care means infrequent or sporadic testing or whose economic circumstances mean limited resources for securing medical testimony. It may also encourage guilty pleas from individuals who, for whatever reason, do not have evidence of what their viral load was at the time of the sexual encounter. ${ }^{109}$ These potential impacts of Mabior are relevant to a consideration of personal stare decisis in this context because they are the same types of concerns regarding over-criminalization identified by Justice McLachlin in Cuerrier.

In acknowledging the uncertainty created by Cuerrier, Chief Justice McLachlin noted in Mabior that "[i]t is a fundamental requirement of the rule of law that a person should be able to predict whether a particular act constitutes a crime at the time he commits the act.... Condemning people for conduct that they could not have reasonably known was criminal is Kafkaesque and anathema to our notions of justice." 110 Unfortunately, Mabior failed to provide the very guidance it purported to offer with these lofty words. It is true that Mabior clarified that, in fact, the use of a condom is not sufficient to avoid conviction. However, by stipulating that an accused that fails to disclose his HIV positive status must not only wear a condom but also have a low viral load, the Court in Mabior introduced new uncertainties: "[l] ow viral load is central to establishing or negating liability and yet the Court spends

Mabior that a significant risk of serious bodily harm, which is established by a realistic possibility of transmission of HIV, "cannot mean any risk however small"' at para 15, citing Mabior, supra note 5 at para 85).

107 The Ontario Court of Appeal seems to agree that, at least with respect to viral load, Mabior imposes this burden on the accused. In Felix, supra note 72, the accused appealed a pre-Mabior conviction of sexual assault stemming from one incident of protected vaginal intercourse. No evidence was led at trial with respect to viral load. Instead of acquitting the accused, the Court of Appeal ordered a new trial. As Steve Coughlan notes “"[o]ne might have argued...that the Crown's failure to provide any evidence about viral load should be seen as its own failing, not as something leading to a new trial.... On the other hand [it does] make sense if it is seen as a chance for the accused to avail himself of a defence which should be heard before he can be convicted.... The Ontario Court of Appeal's decision in this case seems pretty clearly to herald that... the burden will always be placed on the accused" (Steve Coughlan, Annotation of $R$ v Felix, ibid, (2013) 3 CR 7th 223 at 224-25).

This aspect of the decision is very confusing. Chief Justice McLachlin begins by stating that "[o]n the evidence before us, a realistic possibility of transmission is negated by evidence that the accused's viral load was low at the time of intercourse and that condom protection was used" (Mabior, supra note 5 at para 104 [emphasis added]). This phrasing is not exactly imbued with the presumption of innocence. In the following paragraph, she asserts that the usual rules of evidence and proof apply and that the Crown bears the burden of establishing the elements of the offence - a dishonest act and deprivation (a significant risk of serious bodily harm). This would suggest that she means for the Crown to bear the burden of proving lack of condom use and a viral load of something other than low (in order to make out the element of deprivation by demonstrating a realistic possibility of transmission). However, in the next paragraph, she states that "where the Crown has made a prima facie case of deception and deprivation... a tactical burden may fall on the accused to raise a reasonable doubt, by calling evidence that he had a low viral load at the time and that condom protection was used" (ibid at para 105). A rule that places a burden on the accused once the Crown has made a prima facie case does not create a tactical burden - it lowers the Crown's standard of proof. Tactical burdens on the accused arise once the Crown has established its case beyond a reasonable doubt. Woolmington's golden thread was not fashioned in the language of the Crown's "prima facie case." Woolmington $v$ Director of Public Prosecutions, [1935] UKHL 1, [1935] AC 462. disclosure convictions are the result of guilty pleas: 51 percent nationally and 59 percent in Ontario). Mabior, supra note 5 at para 14. 
virtually no time discussing what level counts as "low." ${ }^{\prime 111}$ It is also unclear from Mabior whether it is open to trial judges to find, based on the specific evidentiary record before them, that there is no realistic possibility of transmission because of low viral load. ${ }^{112}$ In affirming the significant risk of serious bodily harm test adopted by the majority in Cuerrier, Chief Justice McLachlin affirmed an approach that causes the very concerns she predicted in her Cuerrier concurrence. "From almost any perspective, Mabior [is a] profoundly disappointing judgment." 113

Recall again the factors that the Supreme Court of Canada indicated should guide a decision to overturn a horizontal precedent: the prior decision fails to reflect Charter values; it creates uncertainty contrary to the values of clarity and certainty that underpin stare decisis; the prior decision disadvantages the accused by expanding the scope of criminal law beyond its normal limits; the prior decision is unworkable in its application; principles of law have developed that undermine the validity of the precedent; facts have so changed, or come to be viewed so differently, as to have deprived the old rule of its justification; the value of correcting the error outweighs the values of adhering to stare decisis; and the legislature is not likely to correct the problem in an expeditious fashion. ${ }^{114}$ Consider the ways in which each of these factors supports the conclusion that the Court in Mabior ought not to have followed its majority decision in Cuerrier.

First, appellate courts need not adhere to horizontal precedent if the prior decision disadvantages the accused by expanding the scope of the criminal law beyond its normal limits. ${ }^{115}$ Cuerrier dramatically expanded the reach of the criminal law to the disfavour of the accused. In the year following Cuerrier, there was a significant spike in the number of prosecutions in Canada. ${ }^{116}$ Following the Supreme Court's subsequent decision in $R$. $v$. Williams, ${ }^{117}$ there was a second sharp increase in the number of cases, which has continued in an upward trend since then. ${ }^{118}$ As previously noted, Canada's criminal law response to the issue of HIV non-disclosure has become one of the most severe in the Western world. ${ }^{119}$

Second, appellate courts should not adhere to a horizontal precedent if the prior decision fails to reflect Charter values. Cuerrier lent itself to an application of the criminal law that

Shaffer, supra note 55 at 473 . The Court does state at one point that 1,500 copies per milliliter is a low viral load, but there is no discussion of whether 1,500 copies per milliliter is sufficiently low or necessarily low (as a standard). In other words, as Don Stuart notes, "there is no definition provided of what constitutes a low viral count." Don Stuart, "Mabior: Compromise, Vagueness and Inconsistency," Case Comment, (2012) 96 CR (6th) 36 at 36. Schaffer, ibid at 474, also notes that it is also unclear from Mabior whether the realistic possibility test applies to other types of sexual activities beyond vaginal intercourse or other types of sexually transmitted infections.

112 See JTC (YC), supra note 106 (concluding that Mabior leaves open this possibility); but see Felix, supra note 72 and Mekonnen, supra note 72 (potentially conflicting Ontario Court of Appeal decisions on the evidentiary burden post-Mabior).

113 Shaffer, supra note 55 at 466.

114 Fraser, supra note 21 at paras 129-37.

$115 \quad$ Ibid at 134.

116 Mykhalovskiy \& Betteridge, supra note 67 at 39.

1172003 SCC 41, [2003] 2 SCR 134 [Williams]. Williams affirmed the test in Cuerrier and applied it in a case involving a charge of aggravated sexual assault. The charge in Cuerrier was aggravated assault. Mykhalovskiy \& Betteridge, supra note 67 at 39 (the authors do note the difficulty of drawing conclusions about the role that these decisions may have played in changing institutional practices regarding the issue of non-disclosure). 
is inconsistent with the Charter values of equality and liberty. ${ }^{120}$ Many scholars have outlined the inequalities against HIV positive individuals, men of colour, and women perpetuated by the criminalization of HIV non-disclosure. ${ }^{121}$ Equality considerations arise not only with respect to these groups. Arguably, the almost hysterical response to HIV as compared to the legal treatment of other communicable and potentially fatal viruses like Hepatitis $\mathrm{C}$ is rooted in homophobia. ${ }^{122} \mathrm{HIV}$ is still a disease that is associated with, and disproportionately affects, the lives of men who have sex with men. ${ }^{123}$ The expressive impact of an unbalanced legal response to non-disclosure of HIV relative to other communicable diseases seems likely to perpetuate the stigmatization of gay men. This is true regardless of who is being charged. ${ }^{124}$ An examination of the post-Cuerrier cases reveals the role of stereotypical thinking about men who have sex with men in the judicial application of the Cuerrier test. The case law suggests a judicial assumption that gay men willingly take sexual risks that courts never impute to heterosexual complainants. ${ }^{125}$ Some courts also seem to allocate more responsibility for knowledge of transmission to complainants in cases involving sex between men than to complainants involved in heterosexual activity. ${ }^{126}$ Lastly, in some post-Cuerrier

In Mabior, supra note 5 at para 43, Chief Justice McLachlin suggests that Charter values demand full recognition of the right to consent or to withhold consent to sexual relations. She offers very little discussion, though, of how the law might achieve this recognition without embracing the even more expansive approach of allowing any genuine deception to vitiate consent on the basis of fraud (this was the approach advanced by Justice L'Heureux-Dubé in Cuerrier, supra note 4). As Justice McLachlin rightly noted in Cuerrier, it is an approach that would place far too great an imposition on individual liberty - a Charter value she virtually ignores in Mabior. She also pays little attention in Mabior to the equality interests of those already marginalized communities that might be disproportionately impacted by the criminalization of non-disclosure or to the liberty interests for which she expressed great concern in Cuerrier. Consideration of Charter values, as with the recognition of Charter rights, requires internal balancing (see e.g. Trinity Western University v British Columbia College of Teachers, 2001 SCC 31, [2001] 1 SCR 772).

121 See e.g. Matthew Weait, Intimacy and Responsibility: The Criminalisation of HIV Transmission (Abingdon, UK: Routledge-Cavendish, 2007).

122 William N Eskridge Jr \& Nan D Hunter, Sexuality, Gender, and the Law, 2nd ed (New York: The Foundation Press, 2004) at 617; Katheleen Guzman, "About Outing: Public Discourse, Private Lives" (1995) 73:4 Wash ULQ 1531 at 1540; Amy D Ronner, "Scouting for Intolerance: The Dale Court's Resurrection of the Medieval Leper" (2002) 11 Law \& Sexuality 53; John Mann, "Preface," The Impact of Homophobia and Other Social Biases on AIDS (San Francisco: Public Media Center, 1996) at 3.

123 UNAIDS, AIDS Epidemic Update, UNAIDS/09.36E/J61706E (November 2009) at 9.

124 Despite comprising almost 60 percent of the HIV positive population in Canada, gay men represent only 20 percent of charges for non-disclosure: see Eric Mykhalovskiy, Glenn Betteridge \& David McLay, HIV Non-Disclosure and the Criminal Law: Establishing Policy Options for Ontario (Toronto: Ontario HIV Treatment Network, 2010) at 12, online: Ontario HIV Treatment Network < www.catie.ca/pdf/ Brochures/HIV-non-disclosure-criminal-law.pdf $>$ at 12. Scholars have offered different hypotheses for why this may be the case - including community norms in the gay community that may discourage reporting incidents of non-disclosure to the police (ibid) and a disinclination on the part of officials to consider gay men equally worthy of legal protection (Grant, "Time to Re-Think Cuerrier," supra note 50). Notably, in recent years, the rate of prosecution of men who have sex with men has risen (Mykhalovskiy, Betteridge \& McLay, ibid at 11).

125 See e.g. $R v$ Pottelberg, 2010 ONSC 5756, [2010] OJ No 5657 (QL) [Pottelberg]. Despite the complainant's testimony to the contrary, the Court in Pottelberg found that there was a reasonable doubt as to whether the complainant would not have engaged in unprotected sex with Pottelberg if he had known that the accused was HIV positive. The Court based this decision on the complainant's past sexual behaviour with other men and his knowledge about the transmission of the HIV virus between men who engage in anal sex. The Court noted that the complainant was very articulate, had volunteered at an HIV/AIDS clinic, and had initiated the unprotected sexual activity with Pottelberg without asking him about his HIV status. A review of every reported English decision since Cuerrier does not produce a single case involving heterosexual sex in which the Court assumes, based on the complainant's prior sexual history, that she would have engaged in unprotected sex even if she had been advised of the accused's HIV status.

126 See e.g. $R$ v Boone, 2012 ONSC 441, [2012] OJ No 256 (QL) [Boone] ("“t]he complainants, as with most of the gay community, are well aware of the risk of exposure to sexually transmitted infections, particularly HIV" at para 39). Boone was eventually convicted of attempted murder and aggravated sexual assault with respect to more than one complainant. There was evidence that he engaged in sex intending to expose HIV negative men to the virus. 
cases courts seem to find gay men to be less credible complainants in ways that are not revealed in non-disclosure cases involving female complainants, but are certainly reflective of the type of reasoning that discredits women in regular sexual assault cases. ${ }^{127}$ The horizontal precedent in Cuerrier, and the application of Cuerrier by lower courts, fails to reflect Charter values.

A third reason identified by the Supreme Court of Canada to overturn one of its own previous decisions is that facts have so changed, or come to be viewed so differently, that the old rule has lost its justification. Consider the shift in factual context in the period between the Cuerrier and Mabior decisions. There have been enormous advances in the knowledge of HIV transmission and infection rates as well as significant development towards the effective treatment of HIV. ${ }^{128}$ While still a serious medical condition, HIV is no longer a life threatening disease for those with access to health care. ${ }^{129}$

Fourth, Cuerrier is a perfect example of a horizontal precedent that should have been overruled in service of the legal certainty and predictability that stare decisis is meant to promote. The Supreme Court of Canada has recognized the futility of binding itself to prior precedent on the basis of a doctrine aimed at promoting certainty and consistency if doing so would be counterproductive to the promotion of certainty and consistency. ${ }^{130}$ Cuerrier, as was acknowledged in Mabior, ${ }^{131}$ created precisely the inconsistency and uncertainty that Justice McLachlin predicted in her Cuerrier concurrence. Yet Mabior not only upheld the problematic significant risk of serious bodily harm test developed in Cuerrier, but gave it an interpretive spin (the realistic possibility of transmission) and an evidentiary framework (a reverse onus) that is likely to create new uncertainties and increased overbreadth. ${ }^{132}$

In Mabior, the Court was faced with precisely the types of circumstances that warrant overturning a horizontal precedent in order to promote the values that the doctrine of precedent is intended to protect. Now consider the relationship between the prior precedent in Cuerrier and the individuated adjudication present in these cases.

The majority decision in Cuerrier was the product of four justices. Nine justices typically preside over cases before the Supreme Court of Canada making Cuerrier's significant change to the common law a decision supported by less than half of the bench. Again, by the time Mabior was decided, Chief Justice McLachlin was the only member of the Cuerrier Court remaining. It matters that Chief Justice McLachlin authored the unanimous decision in Mabior. The stark contrast between (then) Justice McLachlin's position in Cuerrier and the approach she authors in Mabior is difficult to comprehend. In Mabior, Chief Justice McLachlin contradicts almost every point she made 14 years earlier in Cuerrier (points which were validated in the ensuing years subsequent to Cuerrier).

Ibid.

Fraser, supra note 21 at para 132.

Mabior, supra note 5 at paras 3, 19.

Shaffer, supra note 55. 
In Cuerrier, she devised an approach premised on a standard of high risk: an accused must disclose in circumstances where they present a high risk of infection to the complainant. ${ }^{133}$ In Mabior, she states that "[p]rovided people so afflicted act responsibly and pose no risk of harm to others, they should not be put to the choice of disclosing their disease or facing criminalization." 134 In Cuerrier, she emphasizes that it is only unprotected sex that should fall within the criminal law's reach. In Mabior, she determines that a condom (and its 80 percent reduction in risk of infection) ${ }^{135}$ will not suffice. In Cuerrier, she raised concern that the broad extension of the law resulting from the majority's significant risk of serious bodily harm test would adversely impact on liberty and on public health efforts to encourage testing and treatment by driving those with the disease underground. ${ }^{136}$ In Mabior, she affirms the Cuerrier test and expands the reach of the criminal law, and arguably imposes an evidentiary burden on the accused to negate lack of condom use and a viral load other than low.

These contradictions become that much more puzzling when one considers that the only obvious intervening factor during the interlude between her two decisions is a significant improvement in the treatment of HIV such that the risks HIV poses have been reduced. A 14year post-Cuerrier track record has also demonstrated that the very problems regarding overbreadth and uncertainty that Justice McLachlin forecasted would arise, have indeed arisen. In other words, the shift in circumstances in the intervening period only provided more support for her approach in Cuerrier. The conviction with which Justice McLachlin rejected the majority approach in Cuerrier ${ }^{137}$ and the rationale she offered for rejecting it (its overbreadth, uncertainty, and potential inequality) make it almost incomprehensible that, in Mabior, she would author an opinion that not only endorsed the Cuerrier test, but potentially expanded its reach. ${ }^{138}$

One possible explanation is that Chief Justice McLachlin's decision in Mabior reflects a commitment to the principle of stare decisis - a perceived obligation to adhere to the horizontal precedent established by the majority in Cuerrier. This is problematic.

First, as already noted, the values to be protected by adherence to prior precedent were not well-served in this instance. Horizontal precedents should be adhered to by appellate judges who have previously disagreed with the precedent when to do so promotes consistency and coherency. Again, the significant risk of serious bodily harm test in Cuerrier produced

Cuerrier, supra note 4 at para 74.

Mabior, supra note 5 at para 67 [emphasis added]. Confusingly, this sentence followed a paragraph in which Chief Justice McLachlin purported to reject an absolute disclosure approach. Is a standard of "no risk" anything other than an absolute disclosure approach?

Mabior, ibid at para 98.

Cuerrier, supra note 4 at para 55.

For examples of language indicative of this conviction, see Cuerrier, supra note 4 ("[i]n my respectful view, the broad changes proposed by L'Heureux-Dubé J. and Cory J. do not constitute an incremental development of this common law. Rather, they amount to abandoning the common law rule and substituting new principles in its place" at para 44; "Cory J., recognizing the overbreadth of the theory upon which he founds his reasons, attempts to limit it by introducing an ad hoc qualifier: there must be a 'significant risk of serious bodily harm' before consent is vitiated. This limitation, far from solving the problem, introduces new difficulties" at para 48).

While Chief Justice McLachlin did acknowledge in Mabior that the two major criticisms of Cuerrier were uncertainty and overbreadth, she did not acknowledge that they were also her criticisms 14 years prior. More importantly, particularly with respect to the issue of overbreadth, she did nothing in Mabior to respond to the criticism. 
uncertainty and overbreadth. Upholding, in the name of consistency, a decision that creates inconsistency is counterproductive.

Second, Chief Justice McLachlin's adherence to horizontal precedent in Mabior did not promote the institutional legitimacy that the principle of stare decisis is intended to protect - making application of the principle pointless. An appellate judge who has authored a concurrence has engaged in an act of individuated adjudication. In authoring a subsequent decision, significant departure from (and in this case outright contradiction with) one's previous written reasons should be explained in order to avoid the conclusion that the horizontal precedent was adhered to formalistically or without reason. This is particularly true in this case because the very concerns that Justice McLachlin predicted in Cuerrier have occurred. In Mabior, Chief Justice McLachlin makes only one (tangential) reference to her decision in Cuerrier. ${ }^{139}$ Other than this one reference, it is as if Chief Justice McLachlin's Cuerrier concurrence, and the very strong opposition to the significant risk of serious bodily harm test that she articulated, did not exist. ${ }^{140}$ Having individuated her reasoning in Cuerrier despite agreeing with the outcome, why would she then reverse herself on nearly every principled position that she had previously taken? To do so without any explanation, and where nearly every justification for overturning a horizontal precedent that the Supreme Court has identified is present, risks creating the perception that stare decisis is not always applied in a reasoned and thoughtful manner.

Adopting an approach to the criminalization of non-disclosure informed by (then) Justice McLachlin's reasoning in Cuerrier would not avoid all of the problems posed by Canada's current criminal law approach to HIV non-disclosure. The point is not to suggest that Justice McLachlin's approach in Cuerrier offered the perfect solution to this issue. Indeed, as Isabel Grant argues, a better approach would remove non-disclosure of HIV status from the sexual assault criminal law regime and in its stead reintroduce the use of offences such as nuisance and criminal negligence. ${ }^{141}$ Rather, the point is to suggest that what Chief Justice McLachlin did in Mabior was to uphold a deeply problematic legal regime and in the process overturn herself, without explanation, on nearly every single principled objection to this regime that she had previously made.

\section{CONCLUSION}

The principle of stare decisis is thought to serve important functions in a common law system. The practice of a court adhering to its own precedents promotes predictability, certainty, coherence, and institutional legitimacy. However, when an uncertain legal rule is upheld in the name of certainty, or when courts allow their own past mistakes to dictate future directions, the values underpinning the principle of stare decisis are undermined. Similarly, and as is demonstrated by the Supreme Court of Canada's decisions in Cuerrier and Mabior, in some circumstances an individual judge's authorship of a decision which

In Cuerrier, Chief Justice McLachlin concluded that a defendant should only be convicted if he or she actively deceived the complainant (supra note 4 at para 70) - a conclusion she recognized as illogical in Mabior, supra note 5 at paras 63-64.

140 Similarly, in the Court's most recent decision involving the Cuerrier test ( $R v$ Hutchinson, 2014 SCC 19, [2014] 1 SCR 346) Chief Justice McLachlin (with Justice Cromwell) makes no reference to her initial rejection of the significant risk of serious bodily harm test. 
adheres to horizontal precedent rather than personal stare decisis will undermine the coherence of the common law and threaten the legitimacy of the doctrine of precedent. To maintain public faith in the judicial process and the common law system, appellate judges who have engaged in individuated adjudication through authorship of a concurrence should explain a subsequent decision that reverses their original reasoning. 
This page is blank - do not strip it in 